\title{
Local Government Response to COVID-19: Revitalizing Local Democracy in Bangladesh
}

\author{
A.N.M. Zakir Hossain ${ }^{1,2}$ \\ ${ }^{1}$ Faculty of Public Governance and International Studies, National University of Public Service, Budapest 1083, Hungary \\ ${ }^{2}$ Department of Agricultural Economics, Bangladesh Agricultural University, Mymensingh 2202, Bangladesh
}

Corresponding Author Email: anmzakirhossain@bau.edu.bd

https://doi.org/10.18280/ijsdp.160410

Received: 20 April 2021

Accepted: 4 July 2021

\section{Keywords:}

COVID-19, local governance, innovation, participation, service delivery, Bangladesh

\begin{abstract}
The study aims to identify the role of local government and its transformation in response to the COVID-19. It also shows how local governments extended the scope of accountability and transparency to strengthen democracy. The study followed the social survey method and collected data online through Google Docs form. The data were analyzed through descriptive statistics to generate expected results and test the hypothesis by the Spearman correlation coefficient. The study found local governments were positive during COVID-19 to provide services and offered more public engagement in policy formulation, thus more democratic. The health sector has shown the highest priority, with food and environmental services. Inefficient management capacity of leaders and apathy in public engagement hamper resource mobilization at the local level. During COVID-19, ICT intervention and innovation for digital transformation in local governance increased accountability and transparency through easy and effective participation of mass people to strengthen local democracy to respond effectively against COVID-19.
\end{abstract}

\section{INTRODUCTION}

COVID-19 pandemics seized society's spotlights, economy, and governance at local, regional, and global levels irrespective of geographic and political boundaries. It menaced social and economic life, which together generates numerous hazards and jeopardized everyday life. The COVID19 new pandemic challenged traditional methods of policymaking and has forced to generate new forms of governance. However, the nation-state system is being transformed significantly by transnational challenges and forces over time. The current COVID-19 pandemic made the global economy and trade slow down while the ill effects are realized and perceived at a regional and local level. The governments are always keen to monitor the threats and challenges to combat and overcome adversity to secure and accelerate citizens' services. The challenge like COVID-19 pushes the government to shock and feel paralyzed for a while to get back sambit and run again to serve and secure the mass people. So it is necessary to transform the challenges into opportunities through triggering reform and innovations in governance. At the same time, local governments all over the world are fronting enormous challenges to respond against the evil effect of COVID-19. It also put pressure on local governance against COVID-19 to harmonize instant responses and designing the recuperation policies. It is globally proven that the policies arrayed in Iran, Italy, France, South Korea, France, China, and United States worked to slow down the transmission rate. This COVID-19 pandemic has had manifold and extraordinary characteristics that revealed numerous crises that have unique constraints. That is why the central and local government's policies and strategies require harmonization more correctly where the society is heterogeneous and vulnerable groups are fragile. The local government of Bangladesh has a lack of financial and legal freedom that throws those into a vulnerability cycle during the COVID-19 pandemic. Considering the fiscal and managerial arrangements in managing COVID-19 requires local government at COVID19 emergency response coordination epicenter because of brimming uncertainties and to pursue various strategies for managing the crisis [1-3]. These strategies may be classified by the following broad categories- bouncing back and bouncing forward strategies, where the latter underlines selfsufficiency, entrepreneurship, and innovations through transformation and redefining service delivery and core activities with improving the existing services and supplying news services [4-6]. Moreover, it can help to mark and consolidate emotional ties by binding the community to foster a greater sense of facing a threat during a crisis [7]. The epidemic outbreak in Bangladesh uncovered the vulnerability of the health and healthcare system [8] and financial scarcity for public health management like other developing countries due to their uneven society, underdeveloped healthcare system, and prevalent poverty [9]. Besides, recent studies on the covid crisis response have emphasized the role of local government in managing the crisis and promoting the response plan [10]. However, there exists a gap between psychological research and local government practice and service delivery [11]. The local government can play a pivotal role in this crisis to bridge these gaps based on the practical needs for immediate responses around the country. Various governmental policies, including lockdown, made public life more complex and increased the uncertainties in their daily lives [12]. The limited facilities for surveillance and control for citizens during the lockdown regarding the spread of Covid depend on institutional compliance and voluntary information. In 
addition, this pandemic also put pressure on the institutional trust in local governance [13]. At the same time, it is contingent on the economic development at the locality and societal mandate, which needs revisit in this crisis to respond better and more innovative. The central government of Bangladesh has imposed various tools and techniques to efficiently manage the situations and financial threats than any other country in South Asia. Besides, it focuses on building on the anticipatory capacities of local government; however, there is a lack of research on the micro organizational level on their structure, capacity, and process to respond to a crisis. In contrast, studies on anticipatory capacity building recognize it as an enhanced enabling tool for identifying the vulnerabilities of any shocks before they arise [14-17]. Scholars also argued that distinct perception and institutional understanding would determine how and to what extent policy measures will be taken to respond to the crisis $[18,19]$. The local government in Bangladesh itself still freaky based on its location and level in responding to any crisis, which needs to reexamine during the COVID-19 when it is willing to transform the governance pattern and service delivery. Keep in mind the issues mentioned above and the consequences of COVID-19 at local governance; the study focuses on what conditions and mechanism triggered the transformation of local government and how this alteration promotes the democratic culture in local governance.

The study aims to discover and classify the role and innovations of local government in responding to the COVID19 pandemic at the local level that can produce better services for the mass people at an increasing rate of their participation to strengthening local democracy during a crisis. Using primary data gathered by a recent study, the author suggests an intervention of ICT to transform the governance for innovation in governance to increase the participation and accountability to strengthen the local democracy at the local government level. It is widely known that the crisis of COVID19 highlighted in many ways where institutions and stakeholders are stepping up with innovations and supporting each other for sustainable changes. Thus the present study made an example focusing on the conditions that warrant local government transformation. It is also anticipated that the alteration in the administrative culture of service delivery will increase the scope of public engagement in the local authority that ultimately contributes to a more accountable and transparent local government to strengthen local democracy.

\subsection{Local Government of Bangladesh: Policies, Acts and the Legal Framework}

The local government of Bangladesh had a great history connected with the British colonial and Pakistan rule. As the local colonial government focused only on the two main aspects of governance, which were revenue collection and maintaining law order situation over the regime but the current local government is not like that which has been changed in manner and structure as well over the time. The citizen was the center of the governance in both periods until the government's motive and desire changed from police to welfare, which demands a list of terms and responsibilities from both sides. The local government of Bangladesh has seen a number of reorganizations and reforms from its structure and functions; still, the main issues were always outside of the purview of those reforms and reorganization (Table 1). Considering all these limitations and the intervention of ICT in local governance, helping and promoting the participation in service delivery faster and smoothly than earlier though it is not free from challenges like inclusion [20] and urge for consistency for better output [21]. The importance of the local government of Bangladesh has been prioritized in several policy documents for improving the service delivery at a local level. The policies deliver provisions for improvement of the local government machinery to develop their roles to facilitate and designing the required and favorable atmosphere for the necessary services for mass people and multiply the opportunities for the people at their jurisdiction. While these policies emphasized the local government to become more accountable and responsive, it may expand the scope for mass people to access the government's local services and opportunities, focusing on their participation [22]. This is crucial for the critical situation like the COVID-19 pandemic when the country is trying to transforming the local governance.

Extensive studies on local government reform of Bangladesh found that to fulfill the requirements and desires of ruling elites, the local government changed over time [23, 24]. It follows the change of national political regime- as an election overthrew the government, a new government formed, and new policy adapted for the local government [25]. These changes only focus on the local government's narrower issues to control the local bodies by the central government [26], resulting in fewer opportunities for local government bodies to bring services and fulfill the responsibilities for the mass people. However, reform and reorganization efforts failed to focus on those issues but maintain control over the local bodies.

Studies on decentralization found that the country failed to form decentralized governance and promote accountability at the local level. In contrast, dozens of developed and developing countries declared the decentralized reform at their governance for increasing efficiency and responsiveness towards the people [27, 28]. However, recent local government acts and partisan elections at the local level helps to reduce those challenges as they broaden the scope for both the political party and mass people to control the local bodies legally. The primary interest of the ruling party's decentralization is to strengthen their power at the grass-root level and support political education for effective democracy [29-32]. As a result, it is becoming fertile land for leadership development training [24], while the leaders are the driver of alteration in local governance [33]. Whereas previous longterms plans (i.e., 5-year plans) and policies traced local government as vital for strategic and unit of development for governance improvement. Bearing in mind the constitutional guarantee and political economy of the government, decentralized forms of local government are crucial for improving local service delivery to mitigate the regional conflict and fulfill the demands of the community. It also addresses and adapts the technological changes to meet the present and future challenges for smart and timely service delivery of the emerging challenges [26].

The global debate on good governance in the late $1980 \mathrm{~s}$ put an impetus on novel approaches to managing public sectors by highlighting the sensitivity of community demands and accountability in local governance even by the donor agencies during their support for reform in the developing world [34] as twin outcome of good governance [35]. It also emphasizes the transfer of power from the central to the local political unit and relocates the decision making center into sub-national and local government levels [36, 37]. 
Transnational scholarship from research on local government also enticed an extensive assumption that decentralization is a route to bring accountability in regional governance and navigate the government more closely to the mass people to strengthen democracy [38]. It is found from the experimental research in these areas that three Fs (i.e., functions, finance, functionaries) are vital for decentralization to activate and make effective [39]. However, in Bangladesh's case, these are always rigorously imbalanced at the local government level of Bangladesh.

The constitution of Bangladesh guided the establishment of local government bodies by article 59 that offers "(i) Local government in every administrative unit of the Republic shall be entrusted to bodies, composed of persons elected in accordance with law; (ii) it provides the broad functions of local government as: 'administrative and other functions of public officers; the maintenance of public order; the preparation and implementations of plans relating to public service and economic development.' Article 60 provides powers for local governments to impose taxes for local purposes, to prepare their budgets, and to maintain funds'. While the fundamental principles of the state policy declared by the constitution Bangladesh in article no 11 that provides 'the Republic shall be a democracy... in which effective participation by the people through their elected representatives in administration at all levels shall be ensured'
[40].

\subsection{Research objectives}

The general objective of the study is to identify the role of the COVID-19 pandemic in strengthening local democracy through the intervention of ICT at the local government level by increasing transparency and accountability. The specific objectives are;

1. To identify the factors that trigger and lead ICT intervention and digital transformation during COVID-19 at the local government of Bangladesh.

2. To explore the changing role due to innovation and transformation at local governance to build accountability and transparency to strengthen local democracy.

\subsection{Research hypothesis}

1. The intervention of ICT in local governance during COVID-19 has significance in the transformation of governance of Bangladesh.

2. ICT-enabled transformation of governance during COVID-19 has significance in strengthening local democracy in Bangladesh.

Table 1. Policies, acts and commissions related local government of Bangladesh

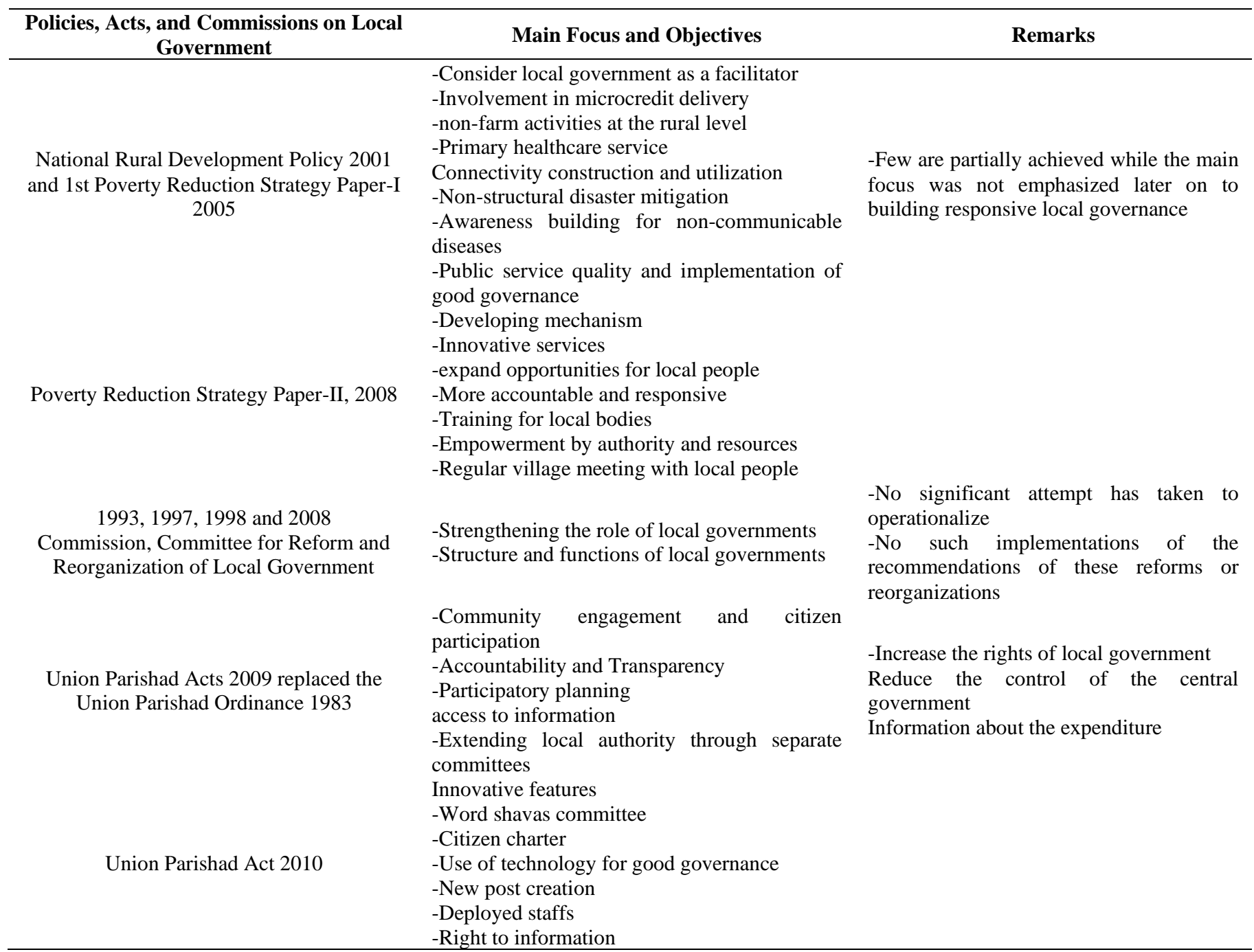




\subsection{Conceptual framework}

The response towards a crisis has always been challenging at any level of the government. However, local government is considered an essential part of crisis management, like the COVID-19 pandemic. The local government involvement in mobilizing the resources and connecting people to ensure participation is crucial to get expected output from the investment of crisis budget. The crisis of COVID-19 has played and spread differently, and their magnitudes varied all over the world as well as the policies yields diverse impact in different societies based on their imposed restrictions and policy mechanisms. That's why the involvement of local government is again reemphasized to manage the current epidemic crisis of COVID-19. The conceptual model examined the effect of COVID-19 responses in the light of ICT intervention to transform the governance through innovation and the increasing rate of participation of mass people for accountability and transparency at the local government of Bangladesh to strengthen local democracy (Figure 1).

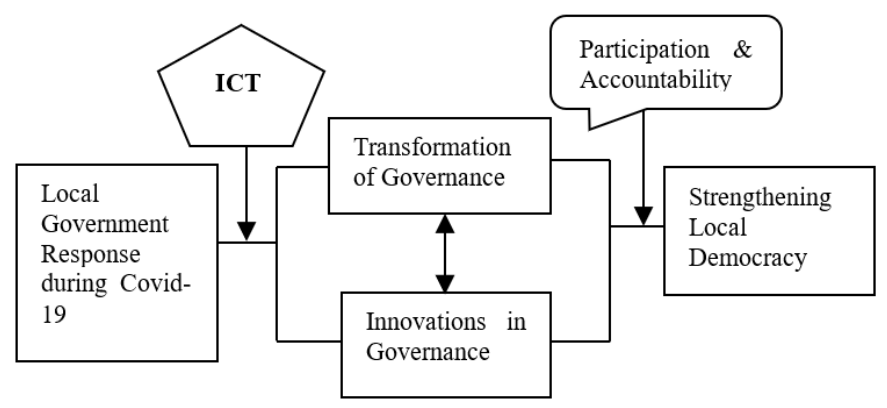

Figure 1. Conceptual framework

This conceptual model shows how to transform conventional governance into an accountable and transparent one that creates more space for popular participation to strengthen local democracy. It also shows how the crisis forced the innovation and transformation of governance and produce a culture that reinforces democratic norms at local governance. The model developed from the reviewed literature and using the key elements (variables) of the local government's innovation and transformation to strengthen democracy during a crisis like COVID-19. Furthermore, it helped prepare the survey questionnaire to collect data to achieve the objectives and test the hypothesis.

\section{METHODOLOGY}

The study was constructed on a survey of local government responses to the COVID-19 crisis and supplemented by analyzing archival data covering managerial, financial, and service delivery at the local government level. The empirical part is based on the analysis of quantitative data from an original online survey conducted in Bangladesh in December 2020, using Google form. The questionnaire was tap into the managerial functions and financial actions of local government, service delivery before and during the COVID19 pandemic, efforts and willingness on an engaging community in policy formulation and implementations, responding to the COVID-19, new service and policy instruments during the pandemic, and innovations in service delivery and public involvement in governance during COVID-19. These can contribute to automation and digital reform in governance to enhance transparency and accountability to strengthening democracy at the local level. We also put questionnaires related to the socio-demographic aspects of the respondents as well.

The study was conducted while local governments were facing tremendous challenges globally in responding to the evil effect of COVID-19. Policy and planning to recovery from and responding to the impact of the COVID-19 pandemic needs coordination immediately due to territorial heterogeneity. The regional and local people are vulnerable in the context of Bangladesh due to several socio-economic and institutional factors that hit can hit harder in this pandemic. Local government typically requires community involvement to function, but their aim is often to attain coordination rather than achieve choice-making consensus per se. A local government body represents an authorized promise to deliver services and execute specific tasks with the local community. Thus participation in decision-making in local governance becomes a cornerstone and central debate in the local government of Bangladesh. This COVID-19 pandemic again urged for such collaboration in managing and overcoming the challenges in local governance.

Due to the current situation and time constraints, the author chose an easy and convenient sample that mainly focused on the graduate students of different faculties of Bangladesh Agricultural University who are from various parts of Bangladesh. The total population size of the university is about 6500 at different study levels. We sent the link to the survey questionnaire to about 500 people through email and social media, i.e., Facebook messenger and WhatsApp, while we received 162 responses from respondents, equaling a response rate of about 32 percent, which is similar to 12.3 percent of the proportion of the population at 95 percent confidence level and 5 percent margin of error. Thus the sample size is representative of the study. The respondents were from every level of local government, i.e., union Parishad, municipality, and city corporations. Interestingly the respondents were from almost around Bangladesh. Though the study has a limitation of the intuitions of the citizen, especially young and middle age, we sent a few survey questionnaires to the older person deliberately to check the data's variability and authenticity to analyze the responses of the youth. We were interested in the behavioral numeric reactions of the people from urban, suburban, and rural areas to make the data nuanced and authentic. It also helps us compare the institutional support and services to respond to the COVID-19 pandemic at different local government levels.

\section{RESULTS AND DISCUSSION}

\subsection{Demographic profile of the respondents}

The demographic profile of the respondents comprises their gender, age, education, area of living, employment, religion, and employment of their family head. These pieces of information are considered crucial while it influences to determine the functional role of the persons. The demographic data reveals that the ratio of the respondents between males and females is 1.6:1. Based on this, about forty percent of the respondents are female. The majority of the respondents are male; however, we sent the survey questionnaire to maintain 
an equal ratio and percentage. Because the development of any society equally depends on both males' and females' contribution and demands equal participation. The majority of respondents $(80 \%)$ are aged below thirty, and only 6.8 percent are more than 35 years old. It indicates that the young generation is more conversant and used to online and the usage of internet in their daily activities and more willing to participate in the study on local governance. It also represents their awareness and increases the availability and access to information among the young generation, crucial for local and national democracy. Education plays a dynamic role for a person as well as for society during their transformation. The study shows that more than ninety percent of respondents have completed their graduation, whereas only eight percent have passed higher secondary school (Figure 2).

Though the education rate is high among the respondents, we find only 33.30 percent are employed, which specifies the country's unemployment problem among university graduates.
More than fifty percent of responses come from the urban area, while only twenty-seven percent from rural areas and the rest are from suburban areas. This stipulates urban people are more active online and more conscious about their socio-political life. Among all of them, 37 percent live in the city corporation area, and 25.30 percent live in the municipality, and 37.70 percent are union level. Bangladesh a Muslim majority country; about ninety percent of the total population of the country is Muslim. In this study, 92 percent of respondents are Muslim, and only 7.40 percent are Hindu.

Furthermore, relating to the respondents' family head's occupation is important as it has significant consequences in the socialization process. The survey data shows that 42 percent of family heads are government service holders. About 15.40 percent are in the private sector, and 14.8 are involved in farming, while 16 percent are in business and 11.70 percent are in other professions (Table 2).

Table 2. Demographic data of the respondent

\begin{tabular}{|c|c|c|c|c|c|}
\hline \multirow{3}{*}{ Gender } & \multicolumn{3}{|c|}{ Female } & & Total \\
\hline & $62.70(100)$ & \multicolumn{2}{|c|}{$38.30(62)$} & & 100 \\
\hline & $0-24$ & $25-30$ & $31-34$ & $35 \leq$ & \\
\hline \multirow{2}{*}{ Age } & $56.2(91)$ & $23.5(38)$ & $13.6(22)$ & $6.8(11)$ & 100 \\
\hline & Post-graduate & \multicolumn{2}{|c|}{ Graduate } & Higher Secondary & \\
\hline \multirow[t]{2}{*}{ Education Level } & $45.06(73)$ & \multirow{2}{*}{\multicolumn{2}{|c|}{$\begin{array}{l}46.92(76) \\
\text { Sub-urban }\end{array}$}} & $8.02(13)$ & 100 \\
\hline & Rural & & & Urban & \\
\hline Living area of respondents & $27.20(44)$ & \multicolumn{2}{|c|}{$21.60(35)$} & $51.20(83)$ & 100 \\
\hline & City Corporation & \multicolumn{2}{|c|}{ Municipality } & Union & \\
\hline Living Local Govt. unit & $37(60)$ & \multirow{2}{*}{\multicolumn{2}{|c|}{$\begin{array}{c}25.30(41) \\
\text { Muslim }\end{array}$}} & $37.70(61)$ & 100 \\
\hline & Hindu & & & Others & \\
\hline Religion of respondents & $7.40(12)$ & \multicolumn{2}{|c|}{$92.00(149)$} & $0.60(1)$ & 100 \\
\hline & Employed & \multicolumn{2}{|c|}{ Not employed } & & \\
\hline Employment status & $33.30(54)$ & \multicolumn{2}{|c|}{$66.70(108)$} & & 100 \\
\hline Occupation of the family head & $\begin{array}{c}\text { Government service } \\
42(68)\end{array}$ & $\begin{array}{c}\text { Private Service } \\
15.40(25)\end{array}$ & $\begin{array}{l}\text { Farming } \\
14.8(24)\end{array}$ & $\begin{array}{c}\text { Others } 11.7 \\
\text { (19) }\end{array}$ & 100 \\
\hline
\end{tabular}

Source: Online Survey Data

\section{Gender based education level of the respondents}

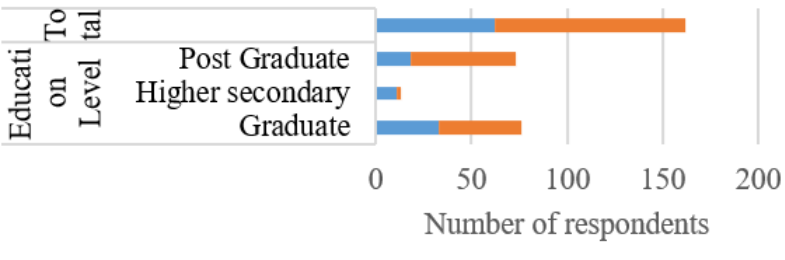

Female $=$ Male

Figure 2. Education level of the respondents

Table 3. Gender-based education of the respondents

\begin{tabular}{cccc}
\hline \multicolumn{3}{c}{ Education Level } & \multirow{2}{*}{ Total } \\
\hline Graduate & Higher secondaryPost Graduate & \\
\hline Female33 (20.37\%) & $11(6.8 \%)$ & $18(11.11 \%)$ & $62(38.27 \%)$ \\
Male $43(26.54 \%)$ & $2(1.23 \%)$ & $55(33.95 \%)$ & $100(61.73 \%)$ \\
Total $76(46.91 \%)$ & $13(8.02 \%)$ & $73(45.06 \%)$ & $162(100 \%)$ \\
\hline
\end{tabular}

The literacy rate of the respondents is awe-inspiring. Simultaneously, the study finds the majority part (71\%) of the women participants are graduate and post-graduate degree holders. In contrast, 98 percent of male participants are graduate and post-graduate degree holders (Table 3 ).

\subsection{Citizen participation in local decision-making process before and after COVID-19 outbreak}

People's participation is imperative for democracy at all levels of governance. Governance, development, and managing any crisis also demand popular participation for well-designed, effective, and practical policy formulation for a productive and sustainable outcome. The constitution of Bangladesh ensured the participation of mass people in every unit of governance, where the local government unit has given special emphasis on different policy documents for strengthening local democracy for equitable and sustainable development. The study found people are not generally involved in their policy and priority settings at the local government level before the COVID-19 outbreak; however, it is a legal aspect of local governance that is not followed evenly in different local government units. More than eighty percent of the respondents believe that the citizens are not engaged in their priority settings, and $17.90 \%$ believe they are engaged (Table 4). On the other hand, $34 \%$ of respondents consider that they are involved in local governance's budget-making process, while $66 \%$ are not (Table 4). This is crucial for both the local government and their inhabitants as the resources are always scarce. During a crisis like COVID-19, it becomes more sensitive to prioritize the local people, which will help manage and distribute more equitably among the stakeholders when their participation will set up the priority. 
The study also found that the highest level (14.1\%) of participation of mass people in setting local priority from the union level while the lowest rate of participation from the city corporation (9.26\%) of local government unit (Table 5) based on the responses of the participants. The study also reveals the rate of invitation from the local government body, which is very low and less than twenty percent altogether and below ten percent in every unit of local government (Table 5). This finding is directly contradictory with the constitutional framework of local governance, which failed to connect their people in their governing process.

Though the local government unit is unwilling to invite their stakeholders in their governing process, the COVID-19 pandemic creates an environment to change their attitudes in the local governance landscape country-wide. The local body has become more willing to consult with their citizen on public policy settings during the crisis of the COVID-19 pandemic, as the respondents reported.

The research finds that 56.80 percent of respondents said the local government body is willing to consult with them to set the local priorities during the COVID-19 pandemic. In comparison, 30.20 percent of respondents find them neutral during this crisis (Table 4). The local government's service delivery is critical for local people, especially during a crisis like COVID-19. In Bangladesh, the response of the local government body towards their citizen in the COVID-19 pandemic was positive. As the author found in this study, 59.30 percent of the participants accept as accurate that their attitudes were positive in service delivery in this COVID-19 period, whereas 11.70 percent do not assume that the local body was positive (Table 4, and Figure 3).

Though the infection rate of the COVID-19 virus wasn't too high, and it was just 26 percent of respondents were infected by the Covid-19 virus, where the rate is comparatively higher in the city area while the lowest is in the rural area (Figure 4).

It was interesting in this study the majority of the people $(82.10 \%)$ said the local government didn't involve their local people in setting a budget, but during the pandemic, they were positive $(56.80 \%)$ to discuss with the people on public policy settings where only 13 percent observed as negative (Table 4).
In the case of service delivery at the local level, 59.30 percent observed that their attitudes were positive during the COVID19 pandemic. In comparison, only 11.70 percent were detected as negative in providing local services (Table 4). These local government attitudes help them introduce a new mode of service delivery, which is decisive in managing crisis and hastening their basic services for the community. The study finds the majority $(80.90 \%)$ of the participants are happy and optimistic about the new services of local government during the pandemic crisis (Table 4).

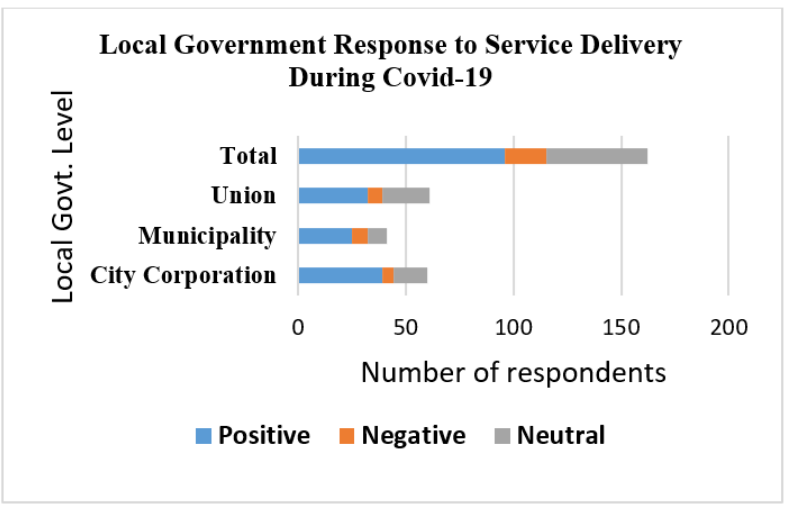

Figure 3. Local government response in service delivery during COVID-19 pandemic

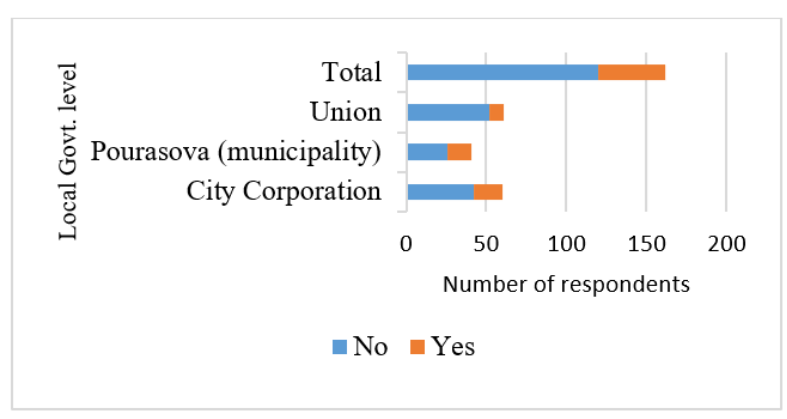

Figure 4. Infection of COVID-19 in the different local government unit

Table 4. Citizen Engagement before COVID-19 and changing attitudes after the pandemic

\begin{tabular}{|c|c|c|c|}
\hline & & Frequency & Percentage \\
\hline \multirow{2}{*}{ Civic engagement activities in setting council priorities before COVID-19 } & Yes & 29 & 17.90 \\
\hline & No & 133 & 82.10 \\
\hline Peonle involved in any hudget molring to some form of vete & Yes & 55 & 34.00 \\
\hline People involved in any budget making to some form of vote & No & 107 & 66.00 \\
\hline & Positive & 92 & 56.80 \\
\hline \multirow[t]{2}{*}{ The attitudes of the council to consult with the public on policy settings during COVID-19 } & Negative & 21 & 13.00 \\
\hline & Neutral & 49 & 30.20 \\
\hline \multirow[t]{3}{*}{ The attitudes of local government on service delivery during COVID-19 } & Negative & 19 & 11.70 \\
\hline & Neutral & 47 & 29.00 \\
\hline & Positive & 131 & 80.90 \\
\hline \multirow[t]{2}{*}{ The response of the mass people when the local government start a new model of service delivery } & Negative & 13 & 8.00 \\
\hline & Neutral & 18 & 11.10 \\
\hline
\end{tabular}

Table 5. Citizen participation in local governance based on their governance level

\begin{tabular}{|c|c|c|c|c|c|c|}
\hline \multirow{2}{*}{$\begin{array}{l}\text { Local } \\
\text { Government Unit }\end{array}$} & \multicolumn{3}{|c|}{$\begin{array}{l}\text { People involved in setting a primary budget at their local } \\
\text { government to some form of vote }\end{array}$} & \multicolumn{3}{|c|}{$\begin{array}{l}\text { Invited to participate in setting the priority of the loca } \\
\text { government before COVID-19 }\end{array}$} \\
\hline & Yes & No & Total & Yes & No & Total \\
\hline City Corporation & $15(9.26 \%)$ & $45(27.78 \%)$ & $60(37.04 \%)$ & $13(8.02 \%)$ & $47(29.01 \%)$ & $60(37.03 \%)$ \\
\hline Municipality & $16(9.88 \%)$ & $25(15.43 \%)$ & $41(25.31 \%)$ & $4(2.47 \%)$ & $37(22.84 \%)$ & $41(25.31 \%)$ \\
\hline Union & $24(14.81 \%)$ & $37(22.84 \%)$ & $61(37.65 \%)$ & $12(7.41 \%)$ & $49(30.25 \%)$ & $61(37.66 \%)$ \\
\hline Total & $55(33.95 \%)$ & $107(66.05 \%)$ & $162(100 \%)$ & $29(17.90)$ & $133(82.10 \%)$ & $162(100 \%)$ \\
\hline
\end{tabular}

Source: Online Survey December 2020 


\subsection{Transparency and Accountability of the Local Government}

Transparency and accountability are the rudimentary cornerstones of democracy and good governance. Leaders around the world are challenged over time for transparency and accountability for their actions. Transparency and accountability also contribute to the responsiveness of local government. COVID-19 pandemic works as a frontrunner in local governance to combat the current challenges and create an opportunity for engaging local people to increase the democratic culture at the local level through new modes of governance. The emergency of the COVID-19 pandemic forced the government to become more and more connected with the local people. The democratic culture of a polity has to confront both of the citizens who are aware and are not aware of their activities. At the same time, it is the responsibility of the local government to make the information public.

In a democracy, many members are not familiar with the suitable means of their contribution and always are not in a position to influence the leaders to become accountable for their activities. The study reveals that the people are not given adequate information from the government side in their locality about the performances of the local government body. More than fifty $(51.90 \%)$ percent of the participants claim that they didn't get any information from their local government authority (Table 6). Even in this COVID-19 pandemic, they are not informed about the council's meetings on priority settings. However, 34.60 percent of respondents argue that they are engaged in designing new policy settings for the local government. In addition, 35.20 percent of the partakers believe their choices are reflected in the policies, while 45.10 percent said maybe their desires are fulfilled by the new policies, and only 19.20 reject them (Table 6). To fulfill the demands of the community requires effective and sustainable use of local resources during this COVID-19 pandemic. More than fifty percent $(54.30 \%)$ of the contributors agreed that the local government policy and budget directed local authority wide to manage the crisis and ensure the sustainable and equitable development for the community (Table 6).

\subsection{Priority Services at Local Government during COVID- 19 Pandemic}

Bangladesh is one of the emerging economies of the world in the 21 st century and maintains steady economic growth in the last decade. The COVID-19 pandemic force to down kneed every economy of the world for the emergency needs during the crisis. As the national government has to bridge-up and minimize the several laps and gaps to mediate the emergency support in this COVID-19 crisis, the local government has chosen and given the best priority for coordinating the available supports and opportunities for the community. This pandemic redefined the role and responsibilities of the local government and the national government and forced them to transform traditional governance. The present study finds that the majority $(59 \%)$ of the participants in this study considers the health sector should be given the highest priority during this COVID-19 pandemic (Figure 5). However, health is related to several interlinked issues, which also be given priority by the local leaders and their bodies.

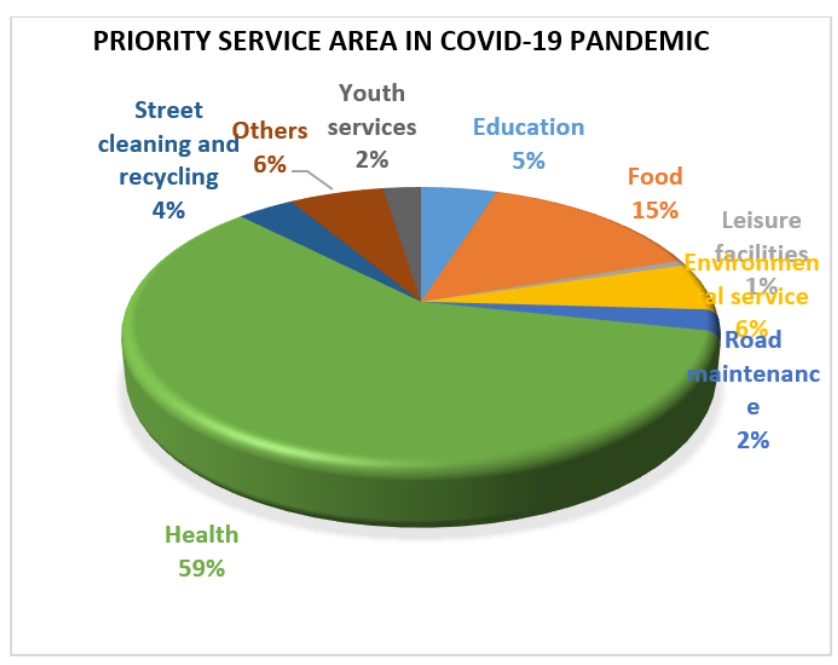

Figure 5. Priority service area during COVID-19 (best one sector)

Table 6. Accountability at the local government level

\begin{tabular}{|c|c|c|c|}
\hline & & Frequency & Percentage \\
\hline \multirow{3}{*}{ Local people are engaged in designing new policy of local government level } & Yes & 56 & 34.60 \\
\hline & No & 58 & 35.80 \\
\hline & Don't know & 48 & 29.60 \\
\hline \multirow{3}{*}{$\begin{array}{l}\text { The local government provide adequate information of their activities before } \\
\text { COVID-19 }\end{array}$} & Yes & 47 & 29.00 \\
\hline & No & 84 & 51.90 \\
\hline & Don't know & 31 & 19.10 \\
\hline \multirow{3}{*}{ Your choices reflected on policy settings during COVID-19 } & Yes & 57 & 35.20 \\
\hline & No & 32 & 19.80 \\
\hline & May be & 73 & 45.10 \\
\hline \multirow{3}{*}{ Local government inform you before council meeting during COVID-19 } & Yes & 47 & 29.00 \\
\hline & No & 92 & 56.80 \\
\hline & Don't know & 23 & 14.20 \\
\hline \multirow{4}{*}{ Geographic level of local government policy and budget directed during COVID-19 } & Neighborhood & 25 & 15.40 \\
\hline & Local authority wide & 88 & 54.30 \\
\hline & Local strategic & 23 & 14.20 \\
\hline & $\begin{array}{c}\text { partnership } \\
\text { Others }\end{array}$ & 26 & 16.00 \\
\hline
\end{tabular}

Source: Online survey data

Access to rights and information with basic healthcare facilities and human rights issues underlines the notion of citizenship during this crisis. The local government can also help reduce the community's knowledge gap about the severity of diseases like COVID-19. The government wants to establish a democratic culture at every level of governance 
through the direct participation of the mass people. This participation will help to establish a more effective and practical democratic approach in policy settings for prioritybased budget allocation for their community. It will also reduce the gap between the government and the governed and increase the chances for future funding through an appropriate manner of taxation and contribution.

The study finds that the health sector should be given the highest priority along with environmental service and ensure food availability during the COVID-19 pandemic (Figure 7). Besides, the authority also provides educational and youth services and street cleaning services as it is crucial during the COVID-19 pandemic to reduce the augmentation and spread of the virus (Figure 6).

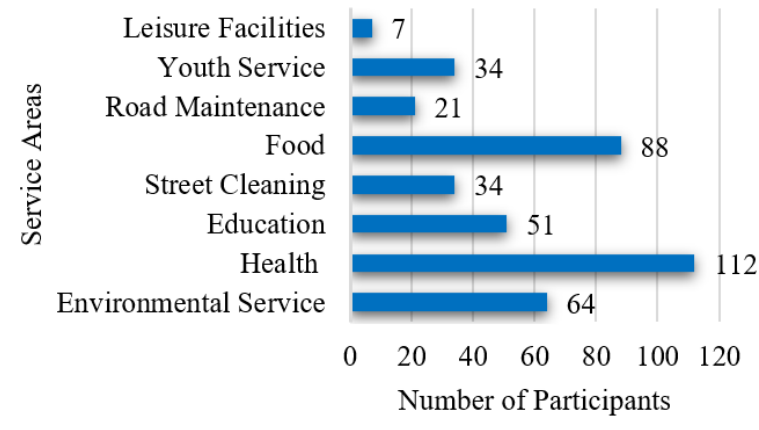

Figure 6. Priority service area during COVID-19 (Best- 3 Sectors), Source: Online Survey Data $(\mathrm{N}=162)$

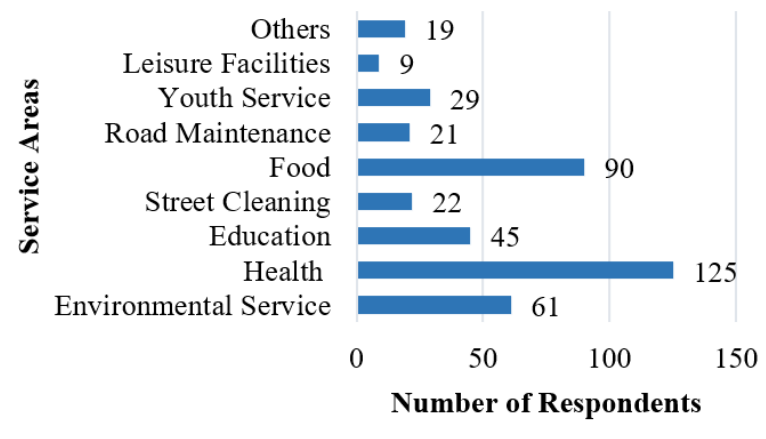

Figure 7. Service areas where funding directed during COVID-19 pandemic (best-3 sectors)

It pronounces that the local community people are aware of the COVID-19 virus and its effects, which is related to the cleanness of the environment and maintaining the personal hygiene issues for the betterment of the greater society, with an adequate supply of food where the participants in this study rightly pointed (Figure 6).

The COVID-19 put pressure on the existing healthcare system because it has created severe vulnerabilities among the mass people irrespective of class, age, and geographic boundaries. The governments at the local, regional, and national are forced to concentrate on public health. The leaders and their governments are morally and ethically bound to allocate their budget for combating the present crisis of COVID-19. The study also finds that most of their local budget is directed towards the health, environmental, and food sector during the COVID-19 pandemic (Figure 7).

\subsection{Challenges of local government}

The local government body has an inherent problem of terms and responsibilities with funding for managing local affairs from its genesis. The historical background of the local government of Bangladesh passed several stages of altering its structure and functionaries, but still, it has the basic problems that prevailed from its birth. The institutionalizing process of local government for good governance was yet not established, while the democratic government passed more than 30 years after the independence. It is the fundamental condition of the constitution for establishing democracy and democratic norms at every level of governance in Bangladesh.

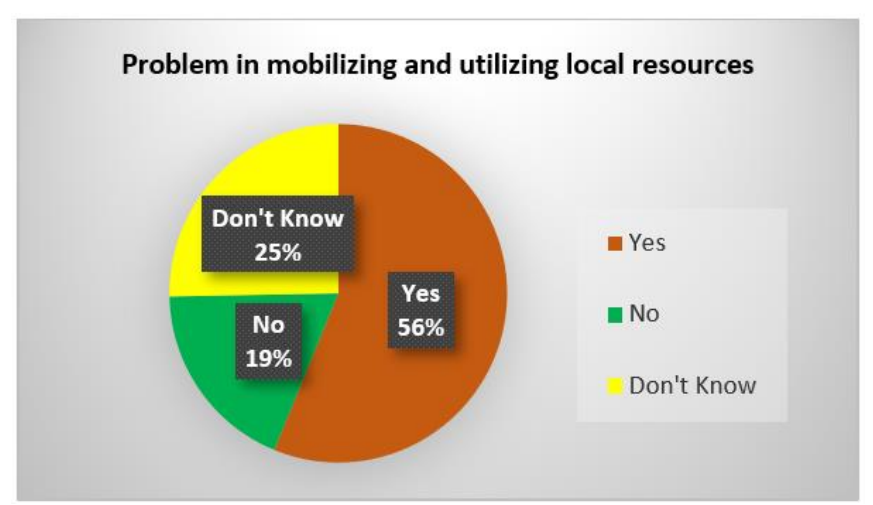

Figure 8. Problems in mobilizing and utilizing local resources

During this COVID-19 crisis, it has been again exposed that public participation is fundamental to institutionalizing local governance and establish democracy at the grass-root level. However, modern technology and ICT intervention in governance have made an opportunity to transform the governance through innovation and connect more people in governing structure for accountability and transparency for strengthening local democracy.

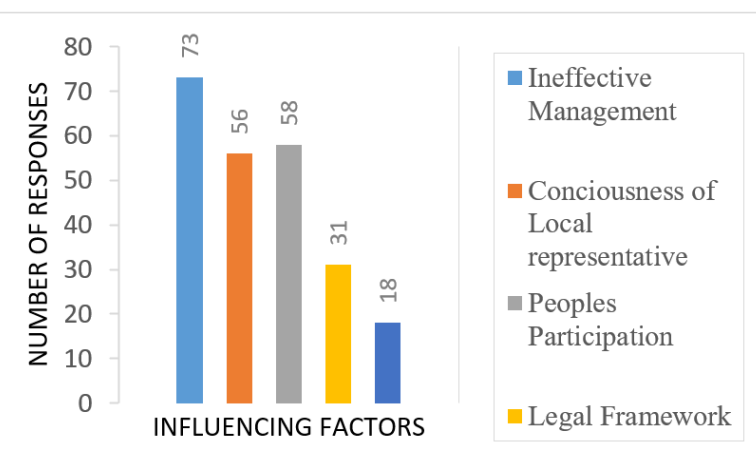

Figure 9. Influencing factors of local government services

The study reveals that there is a problem in mobilizing and utilizing the local resources at the local government level of Bangladesh. More than fifty percent $(56 \%)$ of the respondents agreed that the local government of Bangladesh is currently facing a problem with their local resources to mobilize it and utilize for their community that can yield benefit for them (Figure 8). Though several factors are responsible for these problems, the study finds ineffective management of the resources as the leading one, as per the response of the partakers $(45.1 \%)$. Besides peoples' participation and 
consciousness of local representatives (35.8\% and $34.6 \%$, respectively) are also found as responsible factors for mismanagement and misuse of local resources to good governance and democratic stability at the local government level in Bangladesh (Figure 9). On the other hand, 19\% believe that the legal framework is also impeding the mobilization and utilization of local resources (Figure 9).

\subsection{Strengthening democracy at local government level}

Democracy is the form of popular government and the culture of practice in everyday life in all aspects of national and local government. Governments are keen to establish and promote good governance at all levels for democratic cementation, while the former is the latter's catalyst. The COVID-19 pandemic again put stress on the democratic government while the leaders are struggling the manage the crisis of pandemic and urging for more public participation in policies to reduce the rate of infection and quick recovery from an economic point of view. The global and national policies are affecting and somehow restricted for everyday life while local government body has been given the leading focus and importance to face the challenge to combat the unavoidable COVID-19 crisis. As social distancing is crucial and mass gathering is restricted to minimize the spread of the virus of COVID-19 with lockdown measures, digital transformation in governance works as a tipping point to innovation. It bridgeup the existing gap and offers to increase the accountability and transparency in policy formulation and implementation, thus, ultimately contribute to strengthening the democracy at the local government level.

The evidence from the present study shows that the COVID-19 pandemic offers the mass people an opportunity to engage with the local government. This is a fundamental and building block for democracy, whether at the national or regional level of governance. More than seventy percent of the respondent believe that the crisis of the COVID-19 pandemic offers broader scope to engage with the local government in policy processing and implementation of such policies for their betterment. Among all respondents, 56.20 percent are agreed, and 19.80 percent strongly agree, while only 1.90 percent strongly disagree with the statement (Table 7).

Table 7. ICT intervention and transformation in governance during COVID-19 offered border scope to engage well with the local governance

\begin{tabular}{ccc}
\hline Option & Frequency & Percentage \\
\hline Strongly agree & 32 & 19.80 \\
Agree & 91 & 56.20 \\
Neutral & 24 & 14.80 \\
Disagree & 12 & 7.40 \\
Strongly disagree & 3 & 1.90 \\
Total & 162 & 100 \\
\hline
\end{tabular}

Source: Online survey data December 2020

Table 8. Digitalization can improve participation and accountability to strengthen democracy

\begin{tabular}{ccc}
\hline Option & FrequencyPercentage \\
\hline Strongly agree & 38 & 23.50 \\
Agree & 68 & 42.00 \\
Neutral & 26 & 16.00 \\
Disagree & 8 & 4.90 \\
Strongly disagree & 22 & 13.60 \\
Total & 162 & 100.0 \\
\hline Source: Online survey data, December 2020
\end{tabular}

Table 8 shows that most respondents believe the connection and correlation between digital transformation and strengthening local democracy through the increasing rate of transparency and accountability at the local government level. Forty-two percent of the participants agreed with the statement, and 23.50 percent are strongly agreed, while 4.90 percent have disagreed and 13.60 strongly disagree (Table 8).

\section{Test of Hypothesis One:}

Ho: Intervention of ICT in local governance during COVID19 has no significance in the transformation of governance.

Hi: Intervention of ICT in governance during COVID-19 has significance in the transformation of governance.

Statistical Test of Spearman Correlation Coefficient $\left(r_{s}\right)$

$$
r_{s}=1-\frac{6 \sum d_{i}^{2}}{n^{2}(n-1)}
$$

Table 9. Hypothesis test 1

\begin{tabular}{ccccccc}
\hline Options & Data & Data & Rank & Rank & \multirow{2}{*}{$d_{i}^{2}$} \\
\hline Strongly Agree & 1 & 2 & 1 & 2 & & 0 \\
Agree & 91 & 68 & 1 & 1 & 0 & 0 \\
Neutral & 24 & 26 & 3 & 3 & 0 & 0 \\
Disagree & 12 & 8 & 4 & 5 & - & 1 \\
Strongly & 3 & 22 & 5 & 4 & 1 & 1 \\
Disagree & & & & & & \\
Source: Adapted from tables 7 and 8. & & & &
\end{tabular}

Placed all the values into the above formula, we got the value of $r_{s}$ is $=0.88$ where $\mathrm{n}=5$ (Table 9 ).

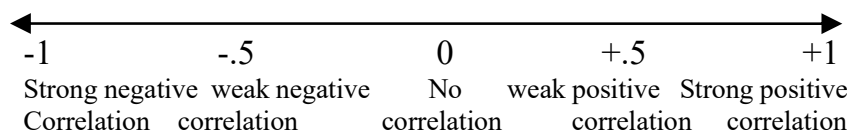

Decision: The outcome of the Spearman Correlation Coefficient $\left(r_{s}=0.88\right)$ indicates a strong positive correlation; thus, the author hereby rejects the Ho and accepts the $\mathrm{Hi}$, which says that "intervention of ICT during COVID-19 has significance in the transformation of governance of Bangladesh."

\section{Test of Hypothesis Two}

H0: ICT-enabled transformation of governance during COVID-19 has no significance in strengthening local democracy.

H1: ICT-enabled transformation of governance during COVID-19 has significance in strengthening local democracy.

Placed all the values into the above formula, we got the value of $r_{s}$ is $=0.88$ where $\mathrm{n}=5$ (Table 10$)$.

$\begin{array}{llccc}\longrightarrow-1 & -.5 & 0 & +.5 & +1 \\ \begin{array}{l}\text { Strong negative } \\ \text { Correlation }\end{array} & \text { correlation negative } & \text { No } & \text { correlation } & \text { weak positive Strong positive } \\ \text { correlation } & \text { correlation }\end{array}$

Decision: The outcome of the Spearman Correlation Coefficient $\left(r_{s}=0.88\right)$ indicates a strong positive correlation; thus, the author hereby rejects the Ho and accepts the $\mathrm{Hi}$, which says that "ICT-enabled transformation of governance 
during COVID-19 has significance in strengthening local democracy in Bangladesh."

Table 10. Hypothesis test 2

\begin{tabular}{ccccccc}
\hline Options & Data 1 & Data 2 & Rank 1 & $\begin{array}{c}\text { Rank } \\
2\end{array}$ & D & $d_{i}^{2}$ \\
\hline Strongly & 38 & 32 & 2 & 2 & 0 & 0 \\
Agree & 68 & 91 & 1 & 1 & 0 & 0 \\
Agree & 26 & 24 & 3 & 3 & 0 & 0 \\
Neutral & 8 & 12 & 5 & 4 & -1 & 1 \\
Disagree & 22 & 3 & 4 & 5 & 1 & 1 \\
Strongly & 22 & \multicolumn{5}{c}{$\sum d_{i}^{2}=2$} \\
Disagree & & &
\end{tabular}

\section{DISCUSSION}

Bangladesh is passing a transitional period to become a middle-income country from a developing country. It has maintained sustained economic growth last few years and doing very well among the emerging countries. The COVID19 pandemic slows down the world economy, while Bangladesh is one of those countries that made a remarkable example in GDP growth rate; however, many issues are there as a developing country. While a new pandemic also attacks this country, and hundreds of thousands of infections spread nationwide that exposed and increased the vulnerabilities of the healthcare system and for the rural and backward people. With the increase of life expectancy healthcare system become more costly while diseases like the COVID-19 pandemic threaten the local and national leaders to pay attention to national security. The societal and economical price of managing an enduring crisis like COVID-19 put leaders and the health sector under stress in several parts of the world. The regional and local government has prioritized coordinating and managing the epidemic, while it can also result in more challenges and vulnerabilities if they failed to administer effectively. The present study reveals that traditional local government bodies are not well equipped in Bangladesh for emergency support with adequate logistics. They are not interested in involving the mass people in the governing process in building trust [41]. This culture at the sub-national level of governance in Bangladesh creates political apathy among the local people. However, ICT nowadays minimizes this gap and bridge-up between them by informing through the intervention of ICT.

The health sector has given priority during this COIVD-19 pandemic, while food and environmental services have also been prioritized. The educational sectors have shut down since March 2020, and few had started online education later in 2020. Education has significant contributions to building and strengthening democracy at every level of governance, irrespective of country and region [42]. It is also crucial for building social justice in any society while education can contribute robustly at the local level [43] and helps to create an environment for training on political education and leadership for strengthening democracy at the grass-root level through the engineering of rules and institution [44]. The success of democracy mostly depends on the significant number of democratic-minded citizens to continue existing [45]. The study found that the education level is high among the participants at every local government level and indicates their connection with the local government and the awareness level of mass people in local government activity. The COVID-19 pandemic force changes the government and citizens' attitudes to consider the governing structure as a juncture of collaboration and coordination to respond to crises and equip them for future crises. As a result, the COVID-19 pandemic helps to refine the existing local governance in practice culture to transform the governance and started to reflect the choices of mass people in policy outcomes. The study also finds that there is still a problem in resource mobilization and utilization for leaders' inefficiency and less participation of community people while legal framework also impeding the process. The trust and responsibilities between the local body and community increased, as found in this study. It also widens the openness of the local government, fetching more transparency when communicating risk during a crisis for citizen's cooperation is vital for democracy [46, 47]. Public awareness and providing food for vulnerable groups of people, mobile health facilities, food for work, and emergency food for ultra-poor from the government through local government prove the national and sub-national government's responsiveness. The rural local body regularly announces the threats and challenges and informs them of available services at their nearest service center for emergency health and food services. Publishing gazettes and news in daily newspapers, leaflets, posters in different places, and billboards also play a significant role in managing the current crisis. The most impressive finding of the study is that most people have faithdigital transformation will help to intensify accountability and transparency and build trust to strengthen local democracy for a sustainable local governing system.

\section{CONCLUSION}

This paper tried to answer the calls- what conditions and mechanisms triggered digital transformation and innovations for local governance during COVID-19 and how they changed their administrative culture and extended the scope of participation to increase local governance's accountability and transparency to strengthen local governance democracy. Evidence from the studies on local government role and effectiveness in epidemic crisis management like COVID-19 advocates that participation and partnership are indeed fundamental for local government to manage the crisis effectively and successfully, which has been proven by the findings of this study also. The performance of local government depends on the particular category of a local government unit. At the same time, it can possibly ensure a distinct substantial contribution for local health and other related services during COVID-19 as the study found different infections at a different level of local government and responses. In this study, the author finds the drivers of local government for transformation and innovation to strengthening democracy are more abstract during the pandemic. Besides depending on the ICT for transformation and innovation, these drivers are the certification of notable performances and the capacity to revitalize the local government structure and intuitions derivative from the past crisis. Furthermore, the author finds the local government body more positive in engaging mass people and connecting them with the governing system with positive attitudes on service delivery. On average, it performed better during the COVID-19 crisis. In short, the likelihood of compelling performances of local government increases with the 
perception of previous experiences during the pandemic, as the author found. It is also revealed that local government increases the latitude and widens the space for more public engagement at governance to fabricate the norms of democracy.

The results of this research suggest the possibilities for further investigation because of the following reasons- i) the potentials of the insightful and adaptive intervention of ICT and transformation of governance should be empirically verified for future sustainability; ii) the success of local government body during the crisis depends on the information distribution and the capacity to coordinate different divide stakeholders, scrutinizing the conditions of connection and collaboration is pivotal to the academic scholars- particularly when both are fascinated in understanding exactly how the crises are overcome governmentally; iii) provided that the identical reasons for local governments innovations were the capacity to involve mass people as the cornerstone for policy settings and this is the high time to reexamine for translating into digitalization in local governance. It will benefit from refining further understanding of the crisis and their lessons and storing for future and utilization in crisis response. The intervention of ICT, innovations, and transformation of governance increases the scope for broader participation while understanding and sharing for collaboration, accountability, and transparency for strengthening local democracy. This interdependence and interconnectivity between local bodies and citizens could reinforce and enable the local government to respond to the contemporary COVID-19 crisis and expand the organizational memory, which may help respond to any unknown crisis that is yet to come.

\section{REFERENCES}

[1] Maher, C.S., Hoang, T., Hindery, A. (2020). Fiscal responses to COVID-19: Evidence from local governments and nonprofits. Public Administration Review, 80(4): 644-650. https://doi.org/10.1111/puar.13238

[2] Boyne, G.A. (2004). A '3Rs' strategy for public service turnaround: retrenchment, repositioning and reorganization. Public Money and Management, 24(2): 97-103. 9302.2004.00401.x

[3] Boyne, G.A. (2006). Strategies for public service turnaround: Lessons from the private sector? Administration \& Society, 38(3): 365-388. https://doi.org/10.1177/0095399705286004

[4] Barbera, C., Jones, M., Korac, S., Saliterer, I., Steccolini, I. (2017). Governmental financial resilience under austerity in Austria, England and Italy: How do local governments cope with financial shocks? Public Administration, $\quad$ 95(3): 670-697. https://doi.org/10.1111/padm.12350

[5] Steccolini, I., Jones, M.D.S., Saliterer, I. (Eds.). (2017). Governmental financial resilience: international perspectives on how local governments face austerity. Emerald Group Publishing.

[6] Barbera, C., Jones, M., Korac, S., Saliterer, I., Steccolini, I. (2021). Local government strategies in the face of shocks and crises: The role of anticipatory capacities and financial vulnerability. International Review of Administrative $\quad$ Sciences, $\quad 87(1)$ : $154-170$. https://doi.org/10.1177/0020852319842661

[7] Greenaway, K.H., Cruwys, T. (2019). The source model of group threat: Responding to internal and external threats. American Psychologist, 74: 218-231. http://dx.doi.org/10.1037/amp0000321

[8] Wilkinson, A. (2020). Local response in health emergencies: Key considerations for addressing the COVID-19 pandemic in informal urban settlements. Environment and Urbanization, 32(2): 503-522. https://doi.org/10.1177/0956247820922843

[9] Dutta, A., Fischer, H.W. (2021). The local governance of COVID-19: Disease prevention and social security in rural India. World Development, 138: 105234. https://doi.org/10.1016/j.worlddev.2020.105234

[10] Anwar, S., Nasrullah, M., Hosen, M.J. (2020). COVID19 and Bangladesh: Challenges and how to address them. Frontiers in Public Health, 8. https://doi.org/10.3389/fpubh.2020.00154

[11] Zhu, Z., Liu, Y., Kapucu, N., Peng, Z. (2020). Online media and trust in government during crisis: The moderating role of sense of security. International Journal of Disaster Risk Reduction, 50: 101717. https://doi.org/10.1016/j.ijdrr.2020.101717

[12] Sibley, C.G., Greaves, L.M., Satherley, N., Wilson, M.S., Overall, N.C., Lee, C.H. (2020). Effects of the COVID19 pandemic and nationwide lockdown on trust, attitudes toward government, and well-being. American $\begin{array}{lll}\text { Psychologist, } & 75(5): & 618 .\end{array}$ http://dx.doi.org/10.1037/amp000066

[13] Van Bavel, J.J., Baicker, K., Boggio, P.S., Capraro, V., Cichocka, A., Cikara, M. (2020). Using social and behavioural science to support COVID-19 pandemic response. Nature Human Behaviour, 4(5): 460-471. http:/doi.org/10.31234/osf.io/y38m9

[14] Lengnick-Hall, C.A., Beck, T.E. (2005). Adaptive fit versus robust transformation: How organizations respond to environmental change. Journal of Management, 31(5): 738-757. https://doi.org/10.1177/0149206305279367

[15] McManus, S., Seville, E., Brunsden, D., Vargo, J. (2007). Resilience management: A framework for assessing and improving the resilience of organisations. Report for the Resilient Organisations Programme, New Zealand.

[16] Linnenluecke, M., Griffiths, A. (2010). Beyond adaptation: Resilience for business in light of climate change and weather extremes. Business \& Society, 49(3): 477-511. https://doi.org/10.1177/0007650310368814

[17] Maher, C.S., Deller, S.C. (2011) Measuring municipal fiscal condition: Do objective measures of fiscal health relate to subjective measures? Journal of Public Budgeting, Accounting \& Financial Management, 23(3): 427-459. https://doi.org/10.1108/JPBAFM-23-03-2011B006

[18] Billings, R.S., Milburn, T.W., Schaalman, M.L. (1980). A model of crisis perception: A theoretical and empirical analysis. Administrative Science Quarterly, pp. 300-316. https://doi.org/10.2307/2392456

[19] Pearson, C.M., Clair, J.A. (1998). Reframing crisis management. Academy of Management Review, 23(1): 59-76. https://doi.org/10.5465/amr.1998.192960

[20] Isaac, T.T., Sadanandan, R. (2020). COVID-19, Public health system and local governance in Kerala. Economic \& Political Weekly, 55(21): 35.

[21] Aziz, A. (2020). Digital inclusion challenges in 
Bangladesh: The case of the National ICT Policy. Contemporary South Asia, 28(3): 304-319. https://dx.doi.org/10.1080/09584935.2020.1793912

[22] Hossain, A.Z., Begum, A., Alam, M.S., Islam, M.S. (2014). Participatory budgeting in Bangladesh local government context. Public Administration Research, 3(2): 28. http://dx.doi.org/10.5539/par.v3n2p28

[23] Westergaard, K. (2000). Decentralization in Bangladesh: local government and NGOs. In Colloquium on Decentralization and Development.

[24] Panday, P.K. (2011). Local Government System in Bangladesh: How far is it decentralized? Lex LocalisJournal of Local Self-Government, 9(3). https://doi.org/10.4335/9.3.205-230(2011)

[25] Khan, Z.R., Hossain, A. (2001). Review/Stocktaking of local governance in Bangladesh. Dhaka: Swiss Agency for International Development and Cooperation (SDC).

[26] Aminuzzaman, S.M. (2010). Local government and development in Bangladesh lessons learned and challenges for improving service delivery of union parishad (UP). Local Governance Support ProjectLearning and Innovation Component (LGSP-LIC).

[27] Channa, A., Faguet, J.P. (2012). Decentralization of health and education in developing countries: A qualityadjusted review of the empirical literature. LSE/STICERD Working Paper No. EOPP 38.

[28] Faguet, J.P. (2012). Decentralization and Popular Democracy: Governance from below in Bolivia. University of Michigan Press.

[29] O'Neill, K. (2005). Decentralizing the State: Elections, Parties, and Local Power in the Andes. Cambridge University Press.

[30] Garman, C., Haggard, S., Willis, E. (2001). Fiscal decentralization: A political theory with Latin American cases. World Politics, 53(2): 205-236. https://doi.org/10.1353/wp.2001.0002

[31] Goldsmith, M., Larsen, H. (2004). Local political leadership: Nordic style. International Journal of Urban and Regional Research, 28(1): 121-133. https://doi.org/10.1111/j.0309-1317.2004.00506.x

[32] Jorna, F. (2015). Openness and urban governance: How transparency erodes local government. Central European Public Administration Review, 13(3-4): 161-183. https://doi.org/10.17573/ipar.2015/3-4.07

[33] Bochel, H., Bochel, C. (2010). Local political leadership and the modernization of local government. Local Government $\quad$ Studies, 36(6): 723-737. https://doi.org/10.1080/03003930.2010.523199

[34] Larbi, G.A. (1999). The new public management approach and crisis states, September. Switzerland.
[35] Minogue, M., Polidano, C., Hulme, D. (1997). Reorganising the state: Towards more inclusive governance. Insight, 23.

[36] Crook, R.C., Crook, R.C., Manor, J. (1998). Democracy and Decentralisation in South Asia and West Africa: Participation, Accountability and Performance. Cambridge University Press.

[37] Sayer, J.A., Elliott, C., Barrow, E., Gretzinger, S., Maginnis, S., McShane, T., Shepherd, G. (2005). The implications for biodiversity conservation of decentralized forest resources management. The Politics of Decentralization: Forests, Power and People, pp. 121137.

[38] Mathebula, N. (2015). Community participation in the South African local government dispensation: a public administration scholastic misnomer. Central European Public Administration Review, 13(3-4): 185-199. https://doi.org/10.17573/ipar.2015.3-4.08

[39] Junaid, A. (2007). Local Government: International Experiences, National Workshop on Strengthening of Local Government Institutions, Dhaka. National Institute of Local Government.

[40] The Constitution of the People's Republic of Bangladesh, Ministry of Law, Justice and Parliamentary Affairs, Government of the People's Republic of Bangladesh.

[41] Scott, V., Crawford-Browne, S., Sanders, D. (2016). Critiquing the response to the Ebola epidemic through a Primary Health Care Approach. BMC Public Health, 16(1): 1-9. https://doi.org/10.1186/s12889-016-3071-4

[42] Alnufaishan, S., Alrashidi, A. (2019). Democracy and Education through the Eyes of Kuwaiti Politicians: A Phenomenological Study. Education Sciences, 9(1): 60. https://doi.org/10.3390/educsci9010060

[43] Camicia, S.P., Knowles, R. (2021). Education for Democracy: A Renewed Approach to Civic Inquiries for Social Justice. IAP.

[44] Spencer, M. (2021). Education and Democracy. Education, 12, 00.

[45] Pelkey, S. (2019). Education and Democracy. MacEwan University Student Research Proceedings, 4(1).

[46] Moon, M.J. (2020). Fighting COVID-19 with agility, transparency, and participation: Wicked policy problems and new governance challenges. Public Administration Review, 80(4): 651-656. https://doi.org/10.1111/puar.13214

[47] Schmidthuber, L., Ingrams, A., Hilgers, D. (2021). Government openness and public trust: The mediating role of democratic capacity. Public Administration Review, $\quad$ 81(1): https://doi.org/10.1111/puar.13298 